\title{
INFORMATION FOR AUTHORS AND READERS
}

NOTES FOR CONTRIBUTORS: The Editors welcome contributions on all aspects and periods of the history of architecture. Enquiries and article manuscripts should in the first instance be sent to the Lead Editor, Anthony Gerbino, via architecturalhistory@sahgb.org.uk. The Editors will advise the address to which a formal submission should be sent. Since the journal is a double blind refereed one, when the article is submitted formally, two printed copies will be required; rough copies of images will suffice at this stage. Full Notes for Contributors are available on the SAHGB website and intending authors are advised to study them carefully.

SUBSCRIPTIONS: Architectural History is published once a year in September. The 2018 price for an online and print subscription for institutions (excluding VAT or sales tax) is $\$ 265.00$ in the USA, Canada and Mexico, and $£ 166.00$ in the UK and elsewhere. The 2018 price for an online-only subscription is $\$ 221.00$ in the USA, Canada and Mexico, and $£ 138.00$ in the UK and elsewhere. EU subscribers (outside the UK) who are not registered for VAT should add VAT at their country's rate. VAT registered subscribers should provide their VAT registration number. Prices include delivery by air when appropriate. Japanese prices for institutions are available from Kinokuniya Company Ltd, P.O. Box 55, Chitose, Tokyo 156, Japan. Orders, which must be accompanied by payment, may be sent to a bookseller, subscription agent or direct to the publisher: Cambridge University Press, Journals Fulfilment Department, UPH, Shaftesbury Road, Cambridge CB2 8BS, UK, email journals@cambridge.org; or in the USA, Canada and Mexico: Cambridge University Press, 40 West 20th Street, New York, NY 1001-4211, email subscriptions_newyork@cambridge.org. Prices include delivery by air. Periodicals postage paid at New York, NY and at additional mailing offices.

PERMISSIONS INFORMATION: All rights reserved. No part of this publication may be reproduced, in any form or by any means, electronic, photocopying or otherwise, without permission in writing from Cambridge University Press. Policies, request forms and contacts are available at http://www.cambridge.org/about-us/rights-permissions. Permission to copy (for users in the USA) is available from Copyright Clearance Center at http:/ / www.copyright. com, email info@copyright.com.

OPEN ACCESS: The SAHGB has been committed since its foundation to the promotion of scholarship in the history of architecture to the widest possible audience. To that end, the journal policy allows authors to archive their manuscript in an institutional repository under the Green Open Access model. Please visit Open Access Publishing at Cambridge (cambridge. org/openaccess) for current information on our Open Access policies, compliance with major funding bodies, and guidelines on depositing your manuscript in an institutional repository.

BACK ISSUES AND DIGITAL ARCHIVE: A full index to vols 1-46, created by the late Professor Andor Gomme, is available at www.sahgb.org.uk, alongside contents lists for more recent volumes. Many of the early volumes of Architectural History are out of print but most recent volumes (save vol. 48) are available, as are some of the Society's monographs. The complete digital archive of the journal is available through the journals homepage with Cambridge University Press at http://cambridge.org/arh. Alternatively, all articles from three or more years ago are available for consultation through JSTOR, a not-for-profit online archive, at www.jstor.org.

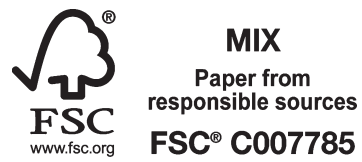

This journal issue has been printed on FSC(Tm)-certified paper and cover board. FSC is an independent, nongovernmental, not-for-profit organisation established to promote the responsible management of the world's forests. Please see www.fsc.org for information. 


\section{ARCHITECTURAL HISTORY}

\section{CONTENTS}

\section{ARTICLES}

Barlborough Hall, Derbyshire

Pete Smith

Hawksmoor's Vision of Wray Wood, Castle Howard

Sally Jeffery

The Picturesque Prospect of Architecture: Thomas Sandby's

Royal Academy Lectures

Sigrid de Jong

The Melville Monument and the Shaping of the Scottish Metropolis

Clarisse Godard Desmarest

'The Visible Embodiment of Modern Commerce': Speculative Office Buildings

in Liverpool, c. 1780-1870

Joseph Sharples

'A Stammering Bundle of Welsh Idealism': Arthur Trystan Edwards and

Principles of Civic Design in Interwar Britain

N.E. Shasore

Dance Halls: Towards an Architectural and Spatial History, c. 1918-65

James Nott

The Design of the Snowdon Aviary and the Nature of Collaboration

David Yeomans

'Money Spinners': R. Seifert \& Partners, Sir Frank Price and Public-Sector

Speculative Development in the 1970s

Ewan Harrison

REVIEWS

\section{SAHGB}

The Society of

Architectural

Historians of

Great Britain 